Working Paper No.33
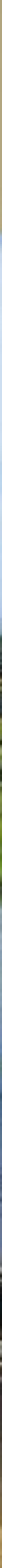

\title{
Asia Pulp \& Paper Indonesia: \\ The business rationale that led to forest degradation and financial collapse
}

Romain Pirard Rofikoh Rokhim 


\title{
Asia Pulp \& Paper Indonesia: The business rationale that led to forest degradation and financial collapse
}

\author{
Romain Pirard \\ Rofikoh Rokhim
}

The authors compiled financial data about the Widjaja Family using Bisnis Indonesia's data collection and Jakarta and Surabaya Stock Exchange resources. We interviewed financial analysts from banking institutions and securities houses, former IBRA staff and NGOs.

The authors wish to thank Christian Cossalter, Alain Karsenty and Chris Barr for their review of the paper and useful advice, and Sally Wellesley for language editing.

Romain Pirard PhD economics student, Ecole des Hautes Etudes en Sciences Sociales (EHESS), France. hosted by CIFOR. Email: r_pirard@yahoo.fr

Rofikoh Rokhim, Editorial \& Research Division, Bisnis Indonesia Daily and PhD economics student from Université Paris 1 Panthéon-Sorbonne. Email: rofikoh.rokhim@malix.univ-paris1.fr 


\section{Disclaimer:}

The views expressed in this publication are those of the author(s)

and do not necessarily represent the official position or policy of CIFOR.

Cover photo by Romain Pirard

\section{Published by}

Center for International Forestry Research

Jl. CIFOR, Situ Gede, Sindang Barang,

Bogor Barat 16680, Indonesia

Tel.: +62 (251) 622622; Fax: +62 (251) 622100

E-mail: cifor@cgiar.org

Web site: http://www.cifor.cgiar.org 


\section{Table of Contents}

$\begin{array}{lr}\text { Introduction } & 1\end{array}$

$\begin{array}{ll}\text { The Widjaja family's control through a complex structure } & 2\end{array}$

The key role of commercial transactions with related parties 3

Investors have their share of responsibility in the APP trajectory 4

$\begin{array}{ll}\text { APP's default and restructuring process } & 5\end{array}$

$\begin{array}{ll}\text { Short-term profits: a recapitulation of financial figures from the 1990s } & 7\end{array}$

$\begin{array}{lr}\text { Legal issues } & 9\end{array}$

$\begin{array}{lr}\text { Conclusions } & 11\end{array}$

$\begin{array}{lr}\text { References } & 14\end{array}$

Annex 1: The story of the Sinar Mas group 16

Annex 2: Pulp and paper and forestry entities related to APP and the Widjaja family 17

Annex 3: Commercial relations between Indonesian P\&P mills and companies related to the Widjaja family

Annex 4: APP Indonesia financial figures 



\section{Introduction}

CIFOR has been involved in research on the Pulp and Paper (P\&P) sector in Indonesia and China since the end of the 1990s. The Barr report, 'Banking on Sustainability: structural adjustment and forestry reform in post-Suharto Indonesia' (2001), was a major step because it stressed the overcapacity problems of the sector at a time when the major groups were facing debt repayment failures. Friends of the Earth has also published reports dating from 2001, that focused on the financial aspects of the sector, with case studies on two groups: Asia Pulp \& Paper (APP, Matthew and Gelder 2001a) and Asia Pacific Resources International Holdings Ltd (APRIL, Matthew and Gelder $2001 \mathrm{~b})$, and showed that the financing strategy of the owners of these groups was a major reason why the past expansion appeared to be fragile.

Since 2001, many things have changed but the financial problems remain. The objective of this report is therefore to use new data sources to get a better understanding. We decided to study APP, as it highlights many of the faults inherent in the Pulp \& Paper sector in Indonesia: excessively rapid expansion, lack of investment in plantation estates, a focus on forest conversion, major use of affiliated domestic banks and foreign investors to finance the expansion, a controversial negotiating process with the Indonesian institution in charge of government-related debts (IBRAthe Indonesian Bank Restructuring Agency), connections to a conglomerate that favours the use of transactions with related parties and potential transfer pricing, and an enormous debt of $\$ 13$ billion that is still to be repaid. All these facts have encouraged us to focus on one group only, which is the largest in Indonesia and with the highest default on debt repayment in an emerging country for a private group. More important to us, its trajectory had significant negative impacts on the natural forests in Indonesia, a country hosting some of the richest forests in the world. It is assumed that its pulp production has resulted in almost one million hectares of natural forests being lost since the beginning of its operations in the mid-1980's (Cossalter 2004), and the group announced it would clear-cut 180,000 hectares of natural forests in 2004/05, mainly on peatlands (Asia Pulp \& Paper 2004). Thus it is of the utmost importance to identify the reasons why such a scenario happened, and to research the rationale behind this apparently harmful strategy for the country, its taxpayers and the environment at large. As the paper will illustrate and argue, the links between the three spheres finance-governance-forests have been very strong and their analysis helps to understand some of the underlying causes of loss of natural forests in Indonesia.

The APP group is supposedly owned ultimately by the Widjaja family, who controls the Indonesian conglomerate Sinar Mas, which is active in many sectors including agribusiness, property and finance. This report provides new information on how the Widjaja family was able to manipulate the numerous entities under its control to generate profits at the expense of minority shareholders' and creditors' interests. We were able to access financial documents dating from the 1990s, and we synthesized the related party transactions in a matrix. Bond prospectuses dating from the 1990s also gave us very useful information on past profits and cost structures, which we synthesized in tables too. Using our knowledge of the forestry operations, we also put into perspective the plausible profits generated by the wood supply from Widjaja-owned companies to the APPowned pulp mills.

The large and rapid expansion of the group's capacity in Indonesia was made possible by

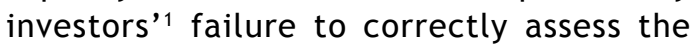
weaknesses and loopholes associated with the sustainability of the pulp and paper mills, the scope for transfer pricing within the Sinar Mas Group, the impossibility of guaranteeing that data in the companies' accounts are true, and the lack of legal enforcement to seize corporate

${ }^{1}$ By "investors" we also mean banks, Export Credit Agencies and other financial institutions involved. 
or personal assets in case of bankruptcy. We interviewed some of the actors involved for an analysis of the reasons behind these. Affiliated banks were also a typical tool for cheap and easy financing, and APP made wide use of this channel. Therefore we investigate this aspect and provide insights.

Finally, as the restructuring process of APP started in 2002 and has now been agreed upon by the vast majority of creditors, we interviewed stakeholders (including the person in charge of the case at IBRA) in order to better understand the ins and outs of the restructuring agreements.

\section{The Widjaja family's control through a complex structure}

The Widjaja family is well known as a major player in the Indonesian economy through the Sinar Mas Group, which was founded by Eka Tjipta Widjaja (see the group's history in Annex 1 ). This family is also considered as the ultimate owner of APP (Fallon 2003). We use the term 'Widjaja family' as we feel it is more correct and appropriate than Sinar Mas or APP. Indeed these groups are not strongly connected in legal terms, through cross-shareholdings, but they are all controlled by the same family.

Figure 1: Structure of the Widjaja family's ownership in Indonesian pulp and paper companies

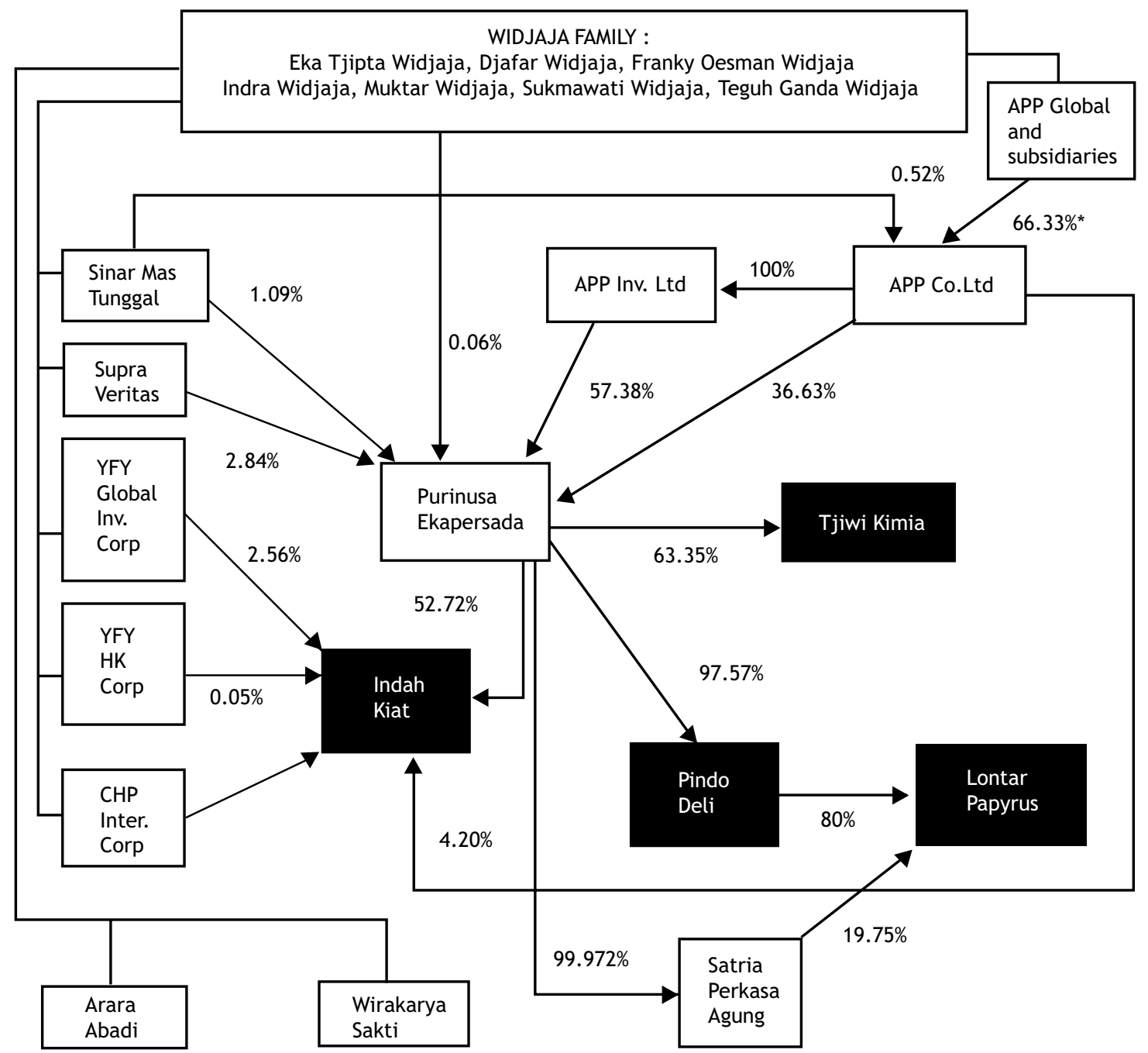

Source: Financial reports 2003 for Indah Kiat-Lontar Papyrus-Pindo Deli-Tjiwi Kimia, Jakarta Stock Exchange, Surabaya Stock Exchange and JSX Watch 2003

* Matthew and Gelder 2001a 
APP is the largest pulp and paper producer in Asia outside Japan, and one of the top ten producers in the world. According to APP Annual Report 1999, the capacity of the group is $\mathbf{8 . 0}$ million tonnes, comprising $\mathbf{2 . 3}$ million tonnes of pulp and 5.7 million tonnes of paper and packaging. APP has 15 production and converting facilities in Indonesia, 12 in China, four in Singapore, two in the United States and one each in India, Mexico and Malaysia (see Figure 2 in Annex 2). APP markets its products in more than 65 countries on six continents. APP's paper products include various types of printing and writing papers, coated and uncoated free sheets, as well as converted and value-added products, such as cut-sized photocopier paper, stationery, carbonless paper, and tissue paper products.

APP was incorporated in Singapore in order to have better access to international financial markets, and is not formally linked to the Sinar Mas Group. But as Figure 1 shows, the real control is actually similar to that of Sinar Mas, as the Widjaja family uses nominee companies established in 'fiscal paradise' countries in order to enjoy various benefits.

\section{The key role of commercial transactions with related parties}

As financial analysts were aware, before the great expansion of APP, the Widjaja family was very keen on using related parties for commercial transactions. This way of doing business is known for allowing and encouraging commercial contracts driven by the interests of the ultimate owners, rather than resulting from a normal market process.

Hundreds of companies have been created within the Sinar Mas conglomerate, both to enhance efficiency and to control sales prices between related companies. As a consequence, the ultimate owners were and still are in position to prioritize their own interests and even capture profits for themselves ${ }^{2}$. This would be done to the detriment of investors in the major listed companies when the share value decreases; and to the detriment of creditors when loans are not repaid. As companies controlled by the Widjaja family are in perpetual business relations with each other, accumulating 'transactions with related parties', outside investors are not in a position to interfere, either because they have only minority rights, or are creditors.

From a theoretical point of view, this phenomenon is clearly shown in Bunkanwanicha et al. (2003) or Claessens and Fan (2003), where ultimate owners minimize their financial implication but maximize their control through the creation of numerous subsidiaries. There is a voluntary gap between the ownership rights (also called cash-flow rights) and the control rights (also called voting rights), the former being equal to the money invested by the ultimate owner in a company through the purchase of shares, and the latter being equal to his power to vote. If we take the example of Indah Kiat (see figure 1), we see that ownership rights by the ultimate owner are diluted along a chain comprising APP Global and subsidiaries, then APP Co. Ltd (with 66.33\%), then APP Inv. Ltd and Purinusa Ekapersada (with 57.38\%), and finally Indah Kiat (with 52.72\%). Another chain comprises APP Global and subsidiaries, then APP Co. Ltd (with 66.33\%), then Purinusa Ekapersada (with 36.6\%), and finally Indah Kiat (with $52.72 \%$ ). And a third chain goes directly from APP Co. Ltd to Indah Kiat $(4,2 \%)$. As a result, the money directly invested by the ultimate owner would be around $35 \%$ but his control rights would remain at more than $50 \%$ (table 1 gives the figures for the other companies). The effect of which was clearly demonstrated by Lemmon and Lins (2003:

Table 1: Ownership rights and control rights of Widjaja Family for APP Indonesian mills

\begin{tabular}{llll}
\hline & $\begin{array}{l}\text { Ownership } \\
\text { rights (O) }\end{array}$ & $\begin{array}{l}\text { Control } \\
\text { rights (C) }\end{array}$ & Ratio O/C \\
\hline Indah Kiat & $35.65 \%$ & $56.92 \%$ & 0.63 \\
\hline Tjiwi Kimia & $39.49 \%$ & $57.38 \%$ & 0.69 \\
\hline Pindo Deli & $60.82 \%$ & $97.57 \%$ & 0.62 \\
\hline $\begin{array}{l}\text { Lontar } \\
\text { Papyrus }\end{array}$ & $60.97 \%$ & $99.75 \%$ & 0.61 \\
\hline
\end{tabular}

Source: Estimated from various sources

\footnotetext{
${ }^{2}$ Lemieux and Wixted (1998) say it clearly: "Financial conglomerates provide opportunities for individuals in control to use the resources of the company for their own personal benefit".
} 
1466), who used a sample of 800 firms in eight East Asian countries, and found that

"cumulative stock returns of firms in which managers and their families separate their control and cash-flow rights through pyramid ownership structures are lower by $12 \%$ during the crisis period compared to those of other firms. Further, we find that the stock return underperformance associated with pyramid ownership structures is present only in firms where the management group also has a high level of control. The underperformance increases to about $20 \%$ points for these firms".

We recapitulate the relations between companies controlled by the Widjaja family in a matrix (presented in Annex 3), categorized according to the nature of the transactions. The matrix proves that these transactions concern the wood supply, energy supply, chemicals supply, the marketing of the pulp and paper products both to domestic and international markets, insurance, the construction of infrastructure, finance, etc.

For example, in 1995 Lontar Papyrus mill signed an agreement with Wirakarya Sakti plantation, which states that the pulp mill has the obligation to finance the plantation company as needed and without any limit (ostensibly for establishing, maintaining and harvesting the plantation), and through the provision of interest-free loans. The agreement also states that the pulp mill is the plantation's priority client for wood sales, at a price to be decided and with payment in advance. Through the late-1990's, APP mills presumably used these agreements to purchase wood at very low costs, amounting to little more than the cost of harvest and transport to the mill. However, this agreement was amended in early 2001 and is valid for another 30 years. All advances paid to Wirakarya Sakti are presented as noncurrent assets.

The same type of agreement has been signed between Indah Kiat mill and Arara Abadi plantation. Both parties also agreed that the 'loans' provided by Indah Kiat shall not be offset against the company's payment obligation from the purchase of pulpwood from Arara. In the financial reports, it is presented as 'non current advances to related parties.'
It is important to stress the consequences of such agreements, as the plantation companies are believed to be owned exclusively by the Widjaja family members. As currently structured, the agreement is totally in favour of the plantation company, and very unusual in the sector. It permits these plantation companies to operate at very low costs (all the more so if the loans are not actually repaid), and to sell their production at very high prices as the mills are affiliated. These transactions lack transparency, presumably on purpose, and the profits generated from these are impossible to calculate precisely. However, we will use some assumptions to estimate these gains in the following sections.

\section{Investors have their share of responsibility in the APP trajectory}

"History, Nehru famously observed, is written by the victors ${ }^{3}$. Financial history, it seems, is written by the creditors. When a financial crisis arises, it is the debtors who are called upon to take the blame. This is odd, since a loan agreement invariably has two parties. When a loan fails, it usually represents miscalculations on both sides of the transaction, or distortions in the lending process itself" (Radelet and Sachs 1998: 1).

Since the beginning, companies related to the Widjaja family have used both banks and capital markets to finance their projects. Locally, the Widjaja family used credits from state-owned or private affiliated banks. Internationally they were also capable of raising substantial funds through bank syndicates from all over the world or the issuance of bonds.

The former director of corporate finance of a dominant player in the international banking sector told us, during a confidential interview held in Jakarta on 21 December 2004, that bankers in the 1990s considered the name of Widjaja as a guarantee in itself, due to his reputation as a successful and reliable business partner: "When we approved the credit for millions of US dollars, we just signed and never asked in detail about the risks of the business". The director said that at that time, international banking was very liquid and bankers were very optimistic about

${ }^{3}$ History is almost written by the victors and conquerors and gives their viewpoint, in Jawaharlal Nehru, The Discovery of India, 1946. 
conglomerate project investments: "It was only after the Asian crisis that the international banking sector began to make more careful analyses. By that time, international investors were already facing losses for some of their credits and marketable securities such as commercial papers or bonds".

APP was solicited aggressively by international banks and investment banks, which soon realized that APP was the most frequent issuer in the emerging markets. In short, in Southeast Asia, APP was the top prospect on most banks' target client list (Fallon 2003). Salomon Smith Barney, in July 1998, even stressed that the crisis in Indonesia had positive impact on APP, due to the fact that its mills generated dollar revenues while most of its operating costs were in rupiah. The volatility of pulp and paper prices would only impact in the short term (Dillon and Waite 1998).

Almost one year later, in June 1999, Morgan Stanley Dean Witter issued an outperform rating and reported that APP was well positioned for Asia's recovery (Spencer et al. 1999). In November 1999, Morgan Stanley reported, “Asia Pulp \& Paper: Here Comes the Cash Flow!”. As investors were worried about the company's ability to repay or finance its US\$1.4 billion debt amortization that would come due in 2000, the report commented that the company would be able to generate enough cash flow in the following year to cover all its financial obligations (Choi, Spencer and Tanoko 1999).

According to Goei Siaw Hong ${ }^{4}$, former chief analyst of Nomura Securities Indonesia, investor enthusiasm to buy and hold the bonds of conglomerates is common. In the case of APP and its subsidiaries, investors primarily considered the Widjaja family's reputation for successful business management. Beside this consideration, the bonds were also issued with a very attractive interest rate, higher than market rates. The analyst also stressed the usual conflict of interest when financial analysts were involved in bond sales, and consequently made overly favourable comments: "It could happen that the analysts made their analysis in order to push the sales, as the bonds were issued by the same securities companies". Moreover, investors in the 1990s were attracted by the Pulp \& Paper industry in Indonesia because they were aware of the abundant natural resources available.

Even after APP showed that it was having difficulty repaying its debts, investors continued to buy bonds related to the Widjaja family, in Duta Pertiwi (the property division; the bonds were oversubscribed), and even in the pulp and paper sector. This was because some financial analysts speculated that a portion of this new debt would be used to pay off the group's shortterm debts.

\section{APP's default and restructuring process}

"Why did things turn out this way?". That may have been the question on the minds of most of the investors when APP announced how severe its financial situation was. After years of significant benefits and continuous expansion, and the regular payment of debts, the group suddenly defaulted in 2001. In fact, signs were already there in 1999 when the government found negative features concerning the Sinar Mas-affiliated bank, Bank Internasional Indonesia (BII).

This bank, part of the Sinar Mas Group, faced difficulties because of its non performing loans. BII issued credits for Sinar Mas companies in many sectors, and financed APP's expansion. This was partially illegal, as the amount of loans to related parties issued by the bank was higher than what was allowed by Indonesian law. The case was never brought to court, but on 28 May 1999, the principal owner (the Widjaja family) was ordered to solve the liquidity problems with the repayment of the loans before 15 April 2001. This was an oral agreement only.

As IBRA (on behalf of the Government of Indonesia) took care of Bll's non performing loans in its attempt to rescue the Indonesian banking system after the Asian crisis, it eventually had $\$ 1.3$ billion of APP's debts in its portfolio. Initially the Widjaja's pledged shares in APP to IBRA as collateral for the Sinar Mas related-party loans. At that time, APP's share price was close to one dollar. However, by late-2000, APP's share price had fallen below US\$0.25, and the Gol became concerned that it did not have adequate collateral. Finally,

\footnotetext{
${ }^{4}$ Jakarta, December 2004.
} 
the Widjaja family had to sign a Shareholder Liability Settlement (PKPS Agreement) with IBRA, which implied that a company with bad loans from a bank that was recapitalized by IBRA had to pledge assets. As a consequence, the Widjaja family pledged $145 \%$ of their debt to IBRA (equivalent to US\$1.9 billion), using APP's corporate assets (Musa and Suta 2004). The new deadline was 15 April 2003.

When, in March 2001, APP called a debt moratorium, the total debt was US\$13.9 billion. Negotiations were then initiated with more than 200 creditors, mostly from the United States, Europe and Japan. During the 1990s, APP's Indonesian operations reported substantial profits, but when APP ran into problems, it told creditors the cash had been fully used. Since the debt moratorium, restructuring negotiations have been coloured by controversy and countless legal challenges.

On 7 November 2001, the Widjaja family agreed with IBRA to give personal guarantees against APP and Sinar Mas debts, and signed a formal document. According to the information we obtained from IBRA staff, the Widjaja family chose to do so in order to gain time. If they had not, they would have had to hand over their assets (pulp and paper mills located in Indonesia) to IBRA. This means that at that time, the restructuring process was based not only on corporate liabilities but on personal liabilities too.

Soon after that, in 2002, I Putu Gede Ary Sutya was replaced as Chairman of IBRA by Syafrudin Tumenggung. This change of management, influenced by Megawati Sukarnoputri's recent election as President of Indonesia, resulted in a change of strategy for APP Indonesia's debt resolution, and the personal guarantees of the Widjaja family disappeared in the process. Indeed, IBRA decided to enter into a global debt restructuring negotiation and to abandon the guarantees it was holding from the Widjaja family and the Sinar Mas Group. Subowo Musa, a former senior manager at IBRA under I Putu Gede Ary Sutya, told us that this happened at the behest of the international creditors. Indeed the IMF, on behalf of these creditors, pressured IBRA to engage in a restructuring involving all creditors at the same level. "It seemed that international creditors were jealous of IBRA because it had these guarantees from the Widjaja” (Subowo Musa pers. com.).
In 2001, APP announced that a $\$ 220$ million loss on two currency swap contracts had not been included in the financial statements, although they had previously been audited by Arthur Andersen. In 2002, the audit report by KPMG revealed that one of its Indonesian subsidiaries, Pindo Deli, had spent US\$170 million in cash to buy a huge piece of land through a Widjaja family-related company. Creditors were upset, as the deal made no economic sense, particularly for a company that was supposedly facing such a financial crisis (FEER 14/02/2002). These two examples were the first of several cases of 'suspect' operations that made investors lose confidence in the management and the reliability of the financial statements between 1997 and 1999. This is very much in line with the words by Fan and Wong (2002):

"It is important for policymakers and regulators to understand how the concentrated share ownership structure in East Asia is associated with incentives for firms to reduce accounting information quality".

On 15 June 2002, IBRA and Export Credit Agencies (ECAs) signed the agreement to arrange the restructuring as soon as possible and also to increase the control of APP companies by the ECAs. Then, on 15 September 2002, there was an agreement that creditors participating in the Master Restructuring Agreement (MRA) could put financial controllers in APP companies. Even IBRA acknowledged that this was ineffective. We should be aware too, that the same year the Deutsche Bank filed a lawsuit in Singapore to appoint a judicial manager, and APP managed to avoid it. Negotiations continued, with several agreements signed during the process, but IBRA was finally considered as too lenient in its approach, contrary to other creditors who were trying to bring the case to court. It resulted in an official protest by 11 ambassadors to Indonesian President Megawati Soekarnoputri, stating that IBRA was apparently influencing the negotiations in favour of the Widjaja family and to the detriment of the creditors. Finally, the Master Restructuring Agreement (MRA) was signed on 30 October 2003, concerning \$6.7 billion of APP Indonesia's debts. Increasingly, the creditors agreed with the document (mainly the ECAs at the beginning, but $93 \%$ by the end of 2004), as further legal action seems hopeless. Not entering into the financial details of the MRA, one has to be aware that several core 
elements of the MRA clearly favored the Widjaja's: i) the payment of the debts was planned during a period longer than fifteen years, ii) until the beginning of the repayment the accrued interests were not included and therefore represent a new financial subsidy to the group, iii) the control of operations was not altered and the ultimate shareholders are still in position to decide of the group's strategy. In short, the MRA did not make a substantial modification to the core reasons why the group followed a rationale that already badly impacted on Indonesian natural forests, on Indonesian taxpayers, and on investors from all around the world.

Some creditors did not enter into the MRA with APP, and in at least one case, they pursued legal action. In early 2005, litigation commenced in New York by GE Capital, Oaktree and Gramercy Adviser was still ongoing (GE Capital finally signed the MRA in 2004). The litigation could eventually lead to the seizure of APP's corporate assets, namely the Indah Kiat and Lontar Papyrus pulp mills, and this is the reason why APP countered with a legal action through the local courts in Sumatra (where the pulp mills are located). Yan Partawijaya, director of the Sinar Mas Group, said that APP will not cooperate with any creditor that decides to keep filing lawsuits because a majority of the creditors have already signed the restructuring agreement (Bisnis Indonesia, 24 January 2005). At the same time, APP asked the creditors to delay the effective date of the agreement until April this year (2005), because of the ongoing litigation. The latest decision in New York, on 7 February 2005, was in favour of APP.

\section{Short-term profits: a recapitulation of financial figures from the $1990 \mathrm{~s}$}

Access to early financial reports and bond prospectuses from the 1990s allowed us to verify some assumptions about the assumed Widjaja family's real strategy: securing shortterm profits with rapid and large expansion of capacity, and delaying costs with longer term debts (bank loans or bonds).

It is striking to see that the shift from profits to losses happened very suddenly, after many years of high profits, as shown in Table 6. From 1993 to 1999, the profits generated by Indah Kiat, Tjiwi
Kimia, Pindo Deli and Lontar Papyrus amounted to, respectively, $\$ 735,974,000, \$ 487,838,000$, $\$ 123,015,000$ and $\$ 168,760$, coming to a total of $\$ 1,515,587,000$.

These profits are realized and registered at the mill level, but they do not include those realized from the domestic sales of the pulp and paper products though companies controlled by the Widjaja family (like Cakrawala Mega Indah), or when the products are marketed to APP-owned mills in China, or even through the wood supply from Widjaja-related plantation companies.

This latter aspect, namely the complete control of the wood supply to the mills, is both very important and controversial. Due to the lack of transparency, there was no official information on the plantation companies' ownership, but past investigations have shown direct links to the Widjaja family. We accessed the companies registration board in Jakarta, and found that Arara Abadi and Wirakarya Sakti are owned fully by the children of Eka Tjipta Widjaja, the founder of Sinar Mas.

From the financial reports of the mills it is not possible to know precisely the price paid for the wood, as the transactions are divided in several categories, and the exact volumes of wood are not specified. However, the mills from the start have mainly purchased wood from the conversion of natural forests inside the plantations' concessions, or of palm oil concessions affiliated to the group. The production costs have been very low, but may increase dramatically from 2005 onwards as the volume of wood from plantations will increase rapidly due to the scarcity of remaining natural forests to convert.

We tried to estimate the price paid for the wood by Lontar Papyrus and Indah Kiat for several years. For this, the Bond Prospectus gave us the percentage of wood purchased by Indah Kiat to affiliated suppliers from 1996 to 1999 , and the financial amounts paid by Indah Kiat and Lontar Papyrus to affiliated suppliers. For the years 2002 and 2003, we could only guess that most of the wood was coming from the affiliated companies, as huge deforestation is taking place in affiliated concessions, and as trees planted in these concessions were starting to be logged at a higher scale than ever before. Moreover, a report by WWF Indonesia (2004) 
Table 2: Estimated price for wood bought from affiliated suppliers

\begin{tabular}{llccrrrr}
\hline & & 1996 & 1997 & 1998 & $1999^{*}$ & 2002 & \multicolumn{2}{c}{2003} \\
\hline \multirow{2}{*}{$\begin{array}{l}\text { Indah } \\
\text { Kiat }\end{array}$} & $\left(\$ / \mathrm{m}^{3}\right)$ & 24.4 & 19.9 & 8.8 & 15.4 & 33.5 & 50 \\
\cline { 2 - 8 } & $\left(\mathrm{Rp} / \mathrm{m}^{3}\right)$ & 58,145 & 92,535 & 70,620 & 109,340 & 299,825 & 445,100 \\
\hline \multirow{2}{*}{$\begin{array}{l}\text { Lontar } \\
\text { Papyrus }\end{array}$} & $\left(\$ / \mathrm{m}^{3}\right)$ & 16 & 10.3 & 5.4 & 17 & 38.7 & 45 \\
\cline { 2 - 8 } & $\left(\mathrm{Rp} / \mathrm{m}^{3}\right)$ & 38,128 & 47,895 & 43,335 & 120,700 & 346,365 & 400,590 \\
\hline
\end{tabular}

Source: adapted from Indah Kiat's 1999 Bond Prospectus, Lontar Papyrus's 2000 Bond Prospectus, the financial reports of Indah Kiat and Lontar Papyrus from 2002 and 2003, APKI for wood consumption, and a conversion factor of $4.5 \mathrm{~m}^{3} /$ ton of pulp produced. Amounts in Rupiah were converted into US dollars according to the exchange rate on 31 December, and vice versa.

*Respectively the first three and nine months of 1999 for Indah Kiat and Lontar Papyrus.

Table 3: Wood consumption by Indah Kiat and Lontar Papyrus, and corresponding rent* for wood supply companies between 1993 and 2003

\begin{tabular}{|c|c|c|c|c|c|c|c|c|c|c|c|}
\hline & & 1994 & 1995 & 1996 & 1997 & 1998 & 1999 & 2000 & 2001 & 2002 & 2003 \\
\hline \multirow[t]{2}{*}{$\begin{array}{l}\text { Indah } \\
\text { Kiat }\end{array}$} & $\begin{array}{l}\text { Wood } \\
\text { purchased } \\
\text { from } \\
\text { affiliated } \\
\text { suppliers } \\
\left({ }^{\prime} 000 \mathrm{~m}^{3}\right)\end{array}$ & 1,090 & 2,815 & 3,142 & 4,338 & 5,558 & 1,364 & 6,393 & 6,480 & 6,523 & 6,534 \\
\hline & $\begin{array}{l}\text { Rent ('000 } \\
\text { US\$) }\end{array}$ & 5,454 & 14,076 & 15,714 & 21,690 & 27,792 & 6,822 & 31,968 & 32,400 & 32,616 & 32,670 \\
\hline \multirow[t]{2}{*}{$\begin{array}{l}\text { Lontar } \\
\text { Papyrus }\end{array}$} & $\begin{array}{l}\text { Wood } \\
\text { purchased } \\
\text { from } \\
\text { affiliated } \\
\text { suppliers } \\
\left({ }^{\prime} 000 \mathrm{~m}^{3}\right)\end{array}$ & 86 & 1,555 & 1,703 & 1,901 & 1,948 & 1,364 & 1,897 & 2,142 & 2,268 & 2,358 \\
\hline & $\begin{array}{l}\text { Rent ('000 } \\
\text { US\$) }\end{array}$ & 432 & 7,776 & 8,514 & 9,504 & 9,738 & 6,822 & 9,486 & 10,710 & 11,340 & 11,790 \\
\hline \multirow[t]{2}{*}{ Total } & $\begin{array}{l}\text { Wood } \\
\text { purchased } \\
\text { from } \\
\text { affiliated } \\
\text { suppliers } \\
\left({ }^{\prime} 000 \mathrm{~m}^{3}\right)\end{array}$ & 1,177 & 4,370 & 4,846 & 6,239 & 7,506 & 2,728 & 8,291 & 8,622 & 8,791 & 8,892 \\
\hline & $\begin{array}{l}\text { Rent ('000 } \\
\text { US\$) }\end{array}$ & 5,886 & 21,852 & 24,228 & 31,194 & 37,530 & 13,644 & 41,454 & 43,110 & 43,956 & 44,460 \\
\hline
\end{tabular}

Source: adapted from Indah Kiat's 1999 Bond Prospectus, Lontar Papyrus's 2000 Bond Prospectus, APKI for wood consumption, a conversion factor $4.5 \mathrm{~m}^{3} /$ ton of pulp produced, assuming wood purchase from affiliated suppliers at $80 \%$ of the fibre used, and $\$ 5 / \mathrm{m}^{3}$ rent for the wood supply from affiliated companies.

* We use the term 'rent' because the supply companies are financed by APP though interest-free loans.

on the timber consumed by APP shows that a major source of wood is from locally obtained clearcut permits, with some of these permits held by affiliated entities. Where non-related companies or cooperatives hold these permits, our own investigations in the field show that affiliated suppliers can buy the wood before selling it back to the mills. Sometimes they can even carry out the logging operations.

Our estimations of the price paid by the mills for the wood do not pretend to be precise, as the public information is not complete. However, they show a trend to an increase of this price, and this can not be entirely justified by a shift from Mixed Tropical Hardwood to Acacia. Indeed, natural forests still represent the bulk of the fiber supply in 2002 and 2003. They also show that this price is unusually high compared to the costs of wood production (Pirard 2004). 
The very clear breakdown in the prices paid by the mills for the wood purchased from the affiliated suppliers, before and after the financial default, may have another explanation than the one officially expressed by Asia Pulp \& Paper. The group says that the shift from natural forest to tree plantations for the wood supply logically increases the costs. But the financial reports clearly state that the plantation operations are financed by the mills, and the same reports show cash transfers of several tens of millions of dollars to the wood suppliers that took place in recent years. This contradicts the official explanation because the prices should not include these costs already paid by the mills. A more convincing reason for the apparent price increase lies in the fact that APP had to attract investors during the expansion in the 1990's, and consequently announced that it could access very cheap fiber from the conversion of natural forests. This has resulted in the huge profits recapitulated in Table 6. After the default in 2001, the agreements were changed presumably in order that the profits get transferred from the mills to the affiliated wood suppliers controlled by the ultimate owners of APP. This is for us the core reason why the prices increased in such a spectacular way from 2001 onwards.

For recent years, according to our own investigations in the field, and assuming shares of wood coming from forest conversion and plantations at $70 \%$ and $30 \%$ respectively, the production costs range between $\$ 20$ and $\$ 25 / \mathrm{m}^{3}$ at most. The resulting profit captured by the wood supplier may then also be in the range of $\$ 15$ to $\$ 30 / \mathrm{m}^{3}$.

For our estimates of the profits (a rent, in fact) captured at the wood supply level, we use a very conservative figure of $\$ 5 / \mathrm{m}^{3}$. In reality, it could be several times higher.

Over the years, the total rent captured amounts to more than $\$ 300$ million with our conservative assumptions. It is plausible that, in reality, this rent is over $\$ 1$ billion.

It is also interesting to calculate the rent that Indonesian pulp mills have captured through the conversion of natural forests. If we assume that until 1998 the fibre used by Indah Kiat and Lontar Papyrus came from the clearcutting of Sumatran forests (a few percent at most may have come from plantations), and that the productivity of these forests for chipwood production was approximately $100 \mathrm{~m}^{3} / \mathrm{ha}$ (Christian Cossalter pers. com.), then we can derive the figures presented in Table 4.

We have already stressed the crucial role of debts in APP's expansion in the 1990s. Table 7 in the Annex 4 recapitulates the evolution of the debt burden for the principal Indonesian mills, and shows the regular increase of these debts, not only generally but also for each of the mills. Some years show a rapid increase, and correspond to the construction of new production lines: 1994, 1995, 1998, 2000.

This increase in the debts has to be compared with the evolution of the capital, as the assets increased generally with the repeated investments. As shown in Graph 1 in the Annex 4, from 1993 to 1997 the debt to equity ratio increased steadily from 1.4 to 1.8 . In 2003 , this ratio reached 3.7 .

In the tables 8 and 9 in the Annex 4 we give recapitulative tables with the evolution of sales and operating costs.

\section{Legal issues}

Our understanding and description of the APP strategy needs to include legal issues for at least two reasons: the group has announced a debt standstill in 2001 but has been able to avoid any seizure of its assets or replacement of the group controllers; legal actions initiated

Table 4: Estimated rent at mill level per hectare of natural forest converted (US\$/ha)

\begin{tabular}{lccccc}
\hline & $\mathbf{1 9 9 4}$ & $\mathbf{1 9 9 5}$ & $\mathbf{1 9 9 6}$ & $\mathbf{1 9 9 7}$ & $\mathbf{1 9 9 8}$ \\
\hline Indah Kiat & 6,127 & 7,268 & 3,534 & 1,946 & 5,850 \\
\hline Lontar Papyrus & - & 4,958 & 1,148 & 4,822 & 2,841 \\
\hline \multicolumn{5}{c}{ Area of natural forests converted (hectares) } \\
\hline Indah Kiat & 10,900 & 28,150 & 31,417 & 43,372 & 55,577 \\
\hline Lontar Papyrus & \multicolumn{7}{c}{15,548} & 17,029 & 19,010 & 19,482 \\
\hline
\end{tabular}


by creditors have generally failed and the debt restructuring has been an out-of-court negotiation.

APP is a multinational with a holding, subsidiaries, and financial companies located in numerous countries, in Singapore, Indonesia, China, Europe or countries known for their lax fiscal regulations, such as Cayman Islands. An efficient move by the creditors to put the group back on its feet, means that all its entities have to be involved as a whole. Unfortunately, "Countries across Asia, whether they are developed or emerging economies, have at least one thing in common: they do not have adequate laws to deal with the insolvency of multinational corporate collapse" (Asian Development Bank 2004: 1). The consequences of this lack of adequate laws to deal with multinationals, such as APP, are at least three:

- First, the risk stands that the transfer of profits among the group entities is in favour of some stakeholders only, and to the detriment of the others. This risk is real according to our analysis of the group management, and the multiplicity of transactions between affiliated (formally or not) companies. It has been minimized, however, through the decision to include the holding and the principal Indonesian operating companies (PIOCs) in the same debt restructuring process that led to the Master Restructuring Agreement (MRA) in late 2003.

- Second, when the indebted holding company is located in a country with a reliable legal system in order to attract investments (APP holding company is incorporated in Singapore), but its assets are owned by subsidiaries located in countries with poor law enforcement, then the lack of cross-border insolvency regime does not allow the holding company creditors to seize its assets. In a report by the World Bank in 2001, the problem for creditors to enforce their rights was stated as follows: "The bankruptcy process in Indonesia does not pose a credible threat to recalcitrant debtors" (Drum 2001: iii). Actually, Indonesia's Bankruptcy Law was amended in 1998, as a result of the economic crisis and in order to address the plethora of corporate failures. It created the Commercial Courts, the first being in
Jakarta, responsible of dealing with the lawsuits filed by creditors. But the first cases were handled improperly, and the reliability of the courts has been widely questioned because of the lack of expertise and rampant corruption. Moreover, a report observes that the number of suits filed in these courts was in regression in 2002 (APEC 2003).

- Third, the lack of possible coordination between legal systems and courts located in different jurisdictions is a reason in itself to refuse any law enforcement against debtors. This point is crucial and was perfectly illustrated by the judgment against the complaint by the Deutsche Bank in Singapore in 2003. As the creditor was calling for the appointment of a judicial manager in APP, the Judge agreed with such a claim but rejected it with the following words:

"I am not at all optimistic that the task can be so easily achieved by such a route. That may well be the case under our system of law but may not be under Chinese or Indonesian law, given the anticipated opposition from creditors of those subsidiaries to the judicial management order in the first place, as well as the conflict in opinions from the parties' Indonesian and Chinese legal advisers [as to whether the Singaporean court judgment would be recognized]" (quoted in ADB 2004).

The complex financial structure of APP, the diversity of creditors and minority shareholders, the enormous quantity of debts (including bonds), have led lawyers to conclude that "Perhaps no restructuring in Asia today better illustrates the challenges of completing a complex, out-of-court, multi-jurisdictional workout than APP" (Cooper and Brown 2003: 11). Concretely, creditors have organized themselves in two Committees but this proved to be ineffective: Export Credit Agencies and commercial banks eventually became aware of their divergent financial interests, and secured bondholders were in conflict with the unsecured ones. Negotiations were thus delayed for a long time, and different strategies emerged with some creditors going to the courts, others accepting the terms designed by APP, or some even separating the Chinese debt from the Indonesian one. 
Delays were in favour of APP of course, and could be anticipated before the conflicts emerged between creditors during the restructuring negotiations. Indeed, judgments in many country's Commercial Courts can be appealed at the Supreme Court, and the final decision could be rendered several years after (APEC 2003). If the short-term strategy of the ultimate owners is the right hypothesis, then this capability to indefinitely postpone the enforcement of legal decisions, through sanctions such as the seizure of assets or the real control of the operations by creditors, clearly works in favor of the owners' interests.

\section{Conclusions}

Asia Pulp \& Paper was studied in this paper as a main factor of deforestation in Indonesia during the two last decades, with an increase in 2004/05 as the group announced its plan to convert 180,000 hectares mainly on peatlands. Curiously, the group defaulted on its debts in 2001 for $\$ 13.9$ billion, but no substantial change was observed in both the control of operations and the management. Thus we researched the factors leading to APP's default, in an analysis that links the spheres of finance, governance, and forests.

APP's trajectory since the early 1990's has been very impressive for several reasons. Focusing at first on Indonesia to develop a pulp and paper empire in order to become one of the top ten producers in the world, the group achieved its objective owing to very lax attitudes on the part of investors both from Indonesia and abroad. The context of the early and mid 1990 s, with the so-called 'Asian miracle' and the Indonesian government's official policy of pushing industries with a clear export-oriented stance, and the availability of huge forest areas for conversion, permitted the extraordinarily fast expansion of APP's capacity. This expansion has been mainly based on debts, either through bond issuance or bank loans. The financial reports and prospectuses show clearly that longterm debts are the major financing vehicle, and that self-financing through benefit reinvestment or share issuance has been relatively small.

The combination of such a financing structure, huge capacity and cheap raw materials resulted in very significant benefits until 2000. Our research estimates these at more than $\$ 1.5$ billion for the four principal APP companies located in Indonesia from 1993 to 1999.

The turning point occurred in 2000, even though 2001 is the well-known year when APP announced a debt standstill. This is clearly not related to the Asian crisis ${ }^{5}$, contrary to what some analysts have declared, but rather to a decline in international pulp and paper prices. The argument that the dollar-denominated debts contracted by the group to finance its expansion explain the deficits does not hold up for us either. Its production costs are mainly in local currency, and, as it is export oriented, its sales are mainly in dollars. We also found out that local sales were priced according to international prices in dollars. And financial analysts were still rating the group well at the end of the 1990s, conscious of the group's formal comparative advantages. Then what happened?

In fact, the losses were related more to the global oversupply of pulp and paper products on the international market, an increase in production costs (for unclear reasons), losses due to foreign exchange rates (registered in the financial reports but not always realized), and other unspecified reasons (the financial reports specify 'other costs' without being any more precise) ${ }^{6}$.

The analysis of the financial reports and bond prospectuses of the principal Indonesian companies under APP gave us the elements for the construction of a matrix, recapitulating the different types of 'transactions with related parties'. These transactions concern the wood supply, energy supply, chemicals supply, the marketing of the pulp and paper products both to domestic and international markets, insurance, the construction of infrastructure, finance, etc. The impressive list of these

\footnotetext{
${ }^{5}$ The group enjoyed great windfall benefits from 1997 to 1999 during the crisis.

${ }^{6}$ A confidential source told us that the creditors' adviser KPMG Singapore had made a study showing that the registered costs were inflated. As quoted in Cooper (2003), creditors have criticized the restructuring plan for some reasons including the lack of "protections preventing cash leakages".
} 
transactions tends to show that the ultimate owners made use of transfer pricing ${ }^{7}$ to move profits, as they have total power of decision.

We looked in particular at the wood supply aspect, and discovered that APP finances the establishment of plantations by the companies presumably owned by the Widjaja family directly, with interest-free loans and without any restrictions. We also estimated the relatively high prices paid by APP pulp mills to these plantation companies, and concluded that this system provides an opportunity to create profits to the detriment of APP itself (but to the advantage of the ultimate owner). Based on very conservative assumptions, we estimate that these profits might represent at least $\$ 300$ million from 1994 to 2003 for the two principal Indonesian pulp mills, Indah Kiat and Lontar Papyrus. In reality, it could be several times higher.

APP's trajectory can be well understood only if one chooses to see it from the point of view of the ultimate owner and the Sinar Mas Group. According to economic theory on debt entrenchment and minority shareholders'/ creditors' financial expropriation, APP may have been created and structured by the Widjaja family in order to enjoy complete control over the decisions and accounts (voting rights), with relatively small direct investment (cash flow rights). This means that these ultimate owners of both the Sinar Mas Group and APP could alone decide the strategy, the commercial agreements and partners, and control the accounts. At the same time the investment of their own capital remained relatively low compared to their power.

All these appearances suggest that APP might be a profitable business ${ }^{8}$, but that the corporate governance resulting from its ownership and financial structure is a key incentive to minimize the profits (either by hiding or moving the profits to other entities). Moreover, since APP defaulted on its debt in 2001, creditors have sought to secure the group's profits to repay debts.
All these findings were obtained through a detailed study of the ownership structure, and the evolution of cash-flows for the principal Indonesian APP subsidiaries.

IBRA, the Indonesian agency created during the crisis with the mandate to rescue the banking sector, was the first stakeholder to identify APP's financial problems. It did so in 1999 when it took over the Sinar Mas-affiliated bank BII, and realized that APP was reluctant to repay its loans to BII. But IBRA's management of the case has been controversial. Its strategy has changed over the years: it put pressure on the Widjaja family when the latter were forced to pledge their personal assets against BII's non performing loans, and it had the power to seize corporate assets at the APP level; but then it associated all the creditors in a global negotiation that led to a restructuring of the debts without any asset guarantees; and finally it sold its debts at discounted prices to unclear entities suspected of being Special Purpose Vehicles under the control of APP's ultimate owners. All these appearances suggest that IBRA's strategy has been strongly influenced by the ultimate owners, who were able not only to enjoy very favourable agreements, but also cancel part of their debts.

In most countries with strong commercial laws, such cases are being taken to the courts of justice. This point is crucial. The theory we discussed in this paper would not be valid where the legal system is functioning, and where a bankruptcy law would force the ultimate shareholders (or at least the group) to render their personal assets (or at least the corporate assets). We showed how the negotiation and restructuring processes seemed to be manipulated to the advantage of the Widjaja family, but we also have to stress the fact that the creditors who have tried to file lawsuits have always lost their case. Last year, over $\$ 550$ million in bonds issued in 1995 by APP International Finance Company B.V. and unconditionally guaranteed by Lontar Papyrus and APP, under the laws of New York, were invalidated by a local district court in Sumatra.

\footnotetext{
7 Transfer pricing is a well-known technique that consists of a transaction between two related entities, with a price based on strategic factors rather than market factors. It is a means for the stakeholders to declare profits or losses at whichever company they choose, for reasons usually linked to tax rates.

${ }^{8}$ Other Pulp \& Paper groups in Indonesia make profits when APP accumulates deficits.
} 
The major lawsuit initiated in New York by GE Capital, Oaktree and Gramercy Advisers, who together hold $\$ 319$ million in debts at Lontar Papyrus, has been rejected. Two major reasons explain why no legal ways can be used to solve the case. First, the absence of a cross-border insolvency regime does not allow courts to act efficiently in this direction. Second, the real weakness of bankruptcy laws and enforcement in Indonesia acts as a shield for APP to keep control of its assets.

We are not very optimistic about the future, because all the above conclusions lead us to a final point: the success or failure of the restructuring process may not impact significantly on the viability of APP's operations. In other words, as APP may be a tool in the hands of the Widjaja family to generate profits for themselves, rather than for the group and its subsidiaries as companies, and as the context does not allow the creditors to influence strategic decisions nor to access the accounts, then we hardly see that the group would radically change its practices. Moreover, the restructuring process has been postponed so far for one reason or another. The most recent example of that is APP's declaration that implementation of the Master Restructuring Agreement will be delayed until at least April 2005 (the agreement was for before 31 January 2004), because the legal documentation was not completed yet (Bisnis Indonesia 24/01/2005).

The major changes we expect are connected to the wood supply side, for two reasons: the increasing scarcity of natural forests is forcing the group to invest massively in large-scale plantation establishment; and the international NGO campaign and APP clients' requirements are forcing the group to be more careful about its wood supply strategy. But the current pulp capacity increase for APP, that is taking place in China and might happen in Indonesia as well in the years to come, should be closely monitored because it leads to more pressure on the natural forests of the region (Pirard and Cossalter 2006). 


\section{References}

APEC, 2003, Study on debt collection litigation/ arbitration in APEC economies, AsiaPacific Economic Forum, $136 \mathrm{p}$.

Asia Pulp \& Paper, 2004, Sustainability Action Plan, Asia Pulp \& Paper Co. Ltd., Jakarta, Indonesia.

Asian Development Bank, 2004, The lack of adequate insolvency frameworks for major corporate collapses in Asia, ADB presentation for the Forum on Asian Insolvency Reform, Session 3, New-Delhi, 26 p, Available on http://adb.bdw.com.

Asia Pulp \& Paper Company Limited, 2000, Annual Report 1999, Singapore.

Barr, Chris, 2001, Banking on sustainability: structural adjustment and forestry reform in post-Suharto Indonesia, WWFCIFOR, Bogor, Indonesia.

Barr, Chris, 2002, Fiber resources, finances, and strategies of Indonesian Pulp and Paper companies: critical challenges facing APP and APRIL, Paper prepared for Senior Management Symposium, Asian Paper, Singapore, April 25-26.

Bunkanwanicha, P., Gupta, J. and Rofikoh Rokhim, 2003, Debt and Entrenchment. Working paper of ROSES, Université Paris 1 Panthéon-Sorbonne, Paris, France.

Choi, A., Spencer, C. and A. Tanoko, 1999, Asia Pulp \& Paper (APP): Here comes the cash flow!, Morgan Stanley Dean Witter, 12 November.

Claessens, Stijn and Joseph P.H. Fan, 2003, Corporate governance in Asia: a survey. Paper prepared for the International Review of Finance.

Cooper, Richard J. and Jennifer Brown, 2003, Asia Pulp and Paper: lessons learned, INSOL World (First Quarter 2003), England.

Cossalter, Christian, 2004, APP Indonesia. New Sustainability Action Plan for Indah Kiat P\&P, Presentation at CIFOR, Bogor, Indonesia.

Dillon, C., and Waite, N. 1998, Asia Pulp \& Paper IQ deceptive-Earning power still strong, Salomon Smith Barney, 1 July.

Drum, B., Tenev, S., Paula Perttunen et al, 2001, Indonesia. Private sector development strategy, WB report, 21581-IND, World Bank, Washington D.C., 36 p.
Fallon, Robert, 2003, Asian Corporate Finance and Business Strategy: Asia Pulp and Paper Company Ltd, Chazen Web Journal of International Business, Colombia Business School, Colombia University, New York, USA.

Fan, J. and T. Wong, 2002, Corporate ownership structure and the informativeness of accounting earnings in East Asia, Journal of accounting and economics, 33 (3), pp 401-25.

Lee, D., 2001, Asia Pulp \& Paper-Coping with growing pains, ABN Amro Asia, 30 January.

Lemieux, Chatarine and John J. Wixted Jr., 1998, Conglomerates, Connected Lending and Prudential Standards: Lessons Learned, Emerging Issues Series Supervision and Regulation Department, Federal Reserve Bank of Chicago, May 1999.

Lemon, M.L. and K.V. Lins, 2003, Ownership structure, corporate governance, and firm value: evidence from the East Asian financial crisis, The journal of finance, LVIII (4), pp 1445-68.

Matthew, E. and von Gelder, J. 2001a, Paper tigers, hidden dragons. The responsibility of international financial institutions for Indonesian forest destruction, social conflict and the financial crisis of Asia Pulp \& Paper, Friends Of the Earth International, Amsterdam.

Matthew, E. and von Gelder, J. 2001b, Paper tigers, hidden dragons 2: APRIL fools. The forest destruction, social conflict and financial crisis of Asia Pacific Resources International Holdings Ltd (APRIL), and the role of financial institutions and paper merchants, Friends Of the Earth International, Amsterdam.

Musa, S. and I. Suta, 2004, BPPN: the end, Yayasan Sad Satria Bhakti, Jakarta, Indonesia.

Pirard, Romain, 2004, Analysis of the operations, production costs and labor at PT Musi Hutan Persada, South Sumatra, Indonesia, CIFOR internal document.

Pirard, Romain and Christian Cossalter, 2006, Brief on Revival of Kalimantan Forest Plantations. Will they contribute to fill in the fiber shortfall of the pulp mills in Sumatra?, Working Paper, CIFOR. 
Radelet, Steven and Jeffrey Sachs, 1998a, The East Asian Financial Crisis : Diagnosis, Remedies, Prospects, Brooking Papers, Washington D.C.

Spencer, C. et al, 1999, Asia Pulp \& Paper: Wellpositioned for Asia's recovery, Morgan Stanley Dean Witter, 28 June.

Wibisono, C., Wibisono, J. and L. Gani, 1997, Conglomeration Indonesia: Regeneration and Transformation into World Class Corporation Entities, Pusat Data Bisnis Indonesia, Jakarta, Indonesia.

World Wide Fund Indonesia, 2004, Legality of timber consumed by Asia Pulp and Paper's mills in Indonesia, JanuaryOctober 2003, Jakarta. 


\section{Annex 1: The story of the Sinar Mas group}

Some of the important milestones in the group's history are as follows:

- Started by selling cakes and candies door-todoor, and then cooking oil, in Ujung Pandang (Sulawesi).

- In the 1950s Eka was appointed to supply the daily needs of troops coming in from Java.

- In 1966 he moved to Jakarta and started an export-import business in various sectors such as oil, plantations, ceramics, metal, steel, textiles and foods.

- In 1972, he moved into the pulp and paper sector with the PT Pabrik Kertas Tjiwi Kimia mill in East Java, with a capacity of 12,000 tonnes of paper.

- Starting in 1980, he developed agribusiness activities such as PT Bimoli and PT Kunci Mas in the palm oil industry, a coconut palm plantation through PT Sadang Las, and tea, coffee and rubber. He eventually grouped these agribusinesses together under the PT Smart Corporation.

- The Widjaja Family initiated investments in the finance sector in 1971 through shareholdings in PT Maskapai Asuransi Djakarta 1945, which operates in shipping and fire insurance. In 1982 they moved into the financial business more seriously by taking over PT Bank Internasional Indonesia (BII) from Iskandar Widjajadi, and establishing PT Internas Arta Finance Company (now PT Sinar Mas Multiartha).

- Two years later Widjaja entered the insurance sector with PT Asuransi Jiwa Purnamala Indonesia (now PT Asuransi Jiwa Eka Life) and PT Asuransi Sinar Mas, and later, PT Sinar Mas Multifinance.

- The property business was started at the same time, with PT Duta Pertiwi Nusantara, PT Sinar Mas Griya, PT Sinarwijaya Ekapratista and PT Bumi Serpong Damai, to develop residences, shopping centres, apartments and office buildings.
Based on Wibisono et al (1997) the Widjaja family's Sinar Mas Group had three holding companies: PT Sinar Mas, PT Sinar Mas Tunggal and PT Supra Veritas. The group is divided into the Trade Division (31 companies), Plantations (25 companies), Livestock (one company), Forestry (two companies), Mining (two companies), Food and Beverages (nine companies), Paper (eight companies), Chemical (14 companies), Non Metallic Minerals (two companies), Basic Metals (two companies), Construction (three companies), Property (eight companies), Tourism (five companies), Industrial Estates (17 companies), Transportation (three companies), Services (seven companies), and Finance (19 companies).

By 1996, the Sinar Mas Group had acquired 45 companies, divested four companies and liquidated one company. At this time, the group had 28 foreign subsidiaries and affiliates, total sales amounting to almost Rp. 12 trillion (the third biggest of 300 conglomerates) with total assets of approximately Rp. 26 trillion (the second largest of 300 conglomerates). 


\section{Annex 2: Pulp and paper and forestry entities related to APP and the Widjaja family}

Figure 2: APP and Widjaja-related companies in the P\&P sector

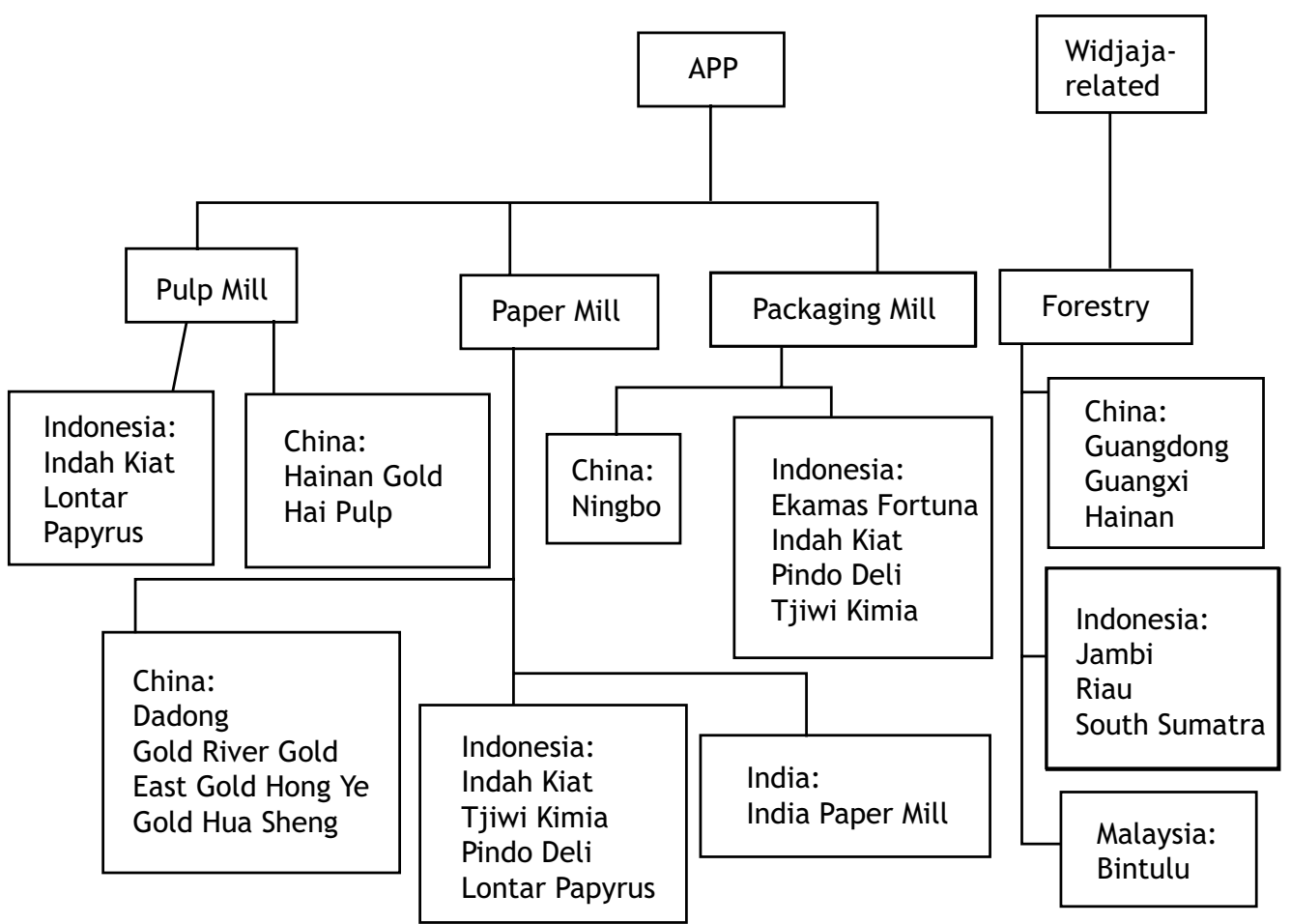

Source: adapted from the APP Annual Report 1999 


\section{Annex 3: Commercial relations between Indonesian Pulp \& Paper mills and companies related to the Widjaja family}

Table 5: Matrix of relations between Indonesian P\&P mills and companies related to the Widjaja family

\begin{tabular}{|c|c|c|c|c|c|c|c|c|c|c|c|c|c|c|c|c|c|c|c|c|c|c|c|c|}
\hline \multirow{2}{*}{ Company Name } & \multicolumn{6}{|c|}{ Indah Kiat } & \multicolumn{6}{|c|}{ Tjiwi Kimia } & \multicolumn{6}{|c|}{ Pindo Deli } & \multicolumn{6}{|c|}{ Lontar Papyrus } \\
\hline & $\mathrm{CR}$ & ST & AP & NR & $\mathrm{D}$ & IN & CR & ST & AP & NR & $\mathrm{D}$ & IN & CR & ST & AP & NR & $\mathrm{D}$ & IN & CR & ST & AP & NR & $\mathrm{D}$ & IN \\
\hline Indah Kiat & & & & & & & * & * & * & * & * & & * & & & & $*$ & & * & * & & * & $*$ & \\
\hline Tjiwi Kimia & * & & & & & & & & & & & & * & * & & & & & & * & & & $*$ & \\
\hline Pindo Deli & * & & & & & & & * & & * & $*$ & & & & & & & & & * & & & * & \\
\hline Lontar Papyrus & * & & & & * & & & & & & & & & & & & & & & & & & & \\
\hline APP Australia & * & & & & & & * & & & * & & & & & & & & & & & & & & \\
\hline APP Belgium & & & & * & & & & & & & & & & & & & & & & & & & & \\
\hline APP Canada & * & & & & & & * & & * & & & & & & & & & & & & & & & \\
\hline APP China & * & & & & & & & & & * & & & & & & & & & & & & & & \\
\hline APP China Trading & & & & * & & & & & & & & & & & & & & & & & & & & \\
\hline APP Co Ltd Singapore & & & & & & & & & * & & ${ }^{*}$ & & * & * & * & * & ${ }^{*}$ & & * & * & * & & & \\
\hline APP Finance Virgin Islands & & & & & & & & & & * & & & & & & & * & & & . & & & * & \\
\hline APP France & * & & & & & & & & & & & & & * & & & & & & * & & & & \\
\hline APP Hong Kong & * & & & * & & & * & & & & & & & & & & & & & * & & * & & \\
\hline $\begin{array}{l}\text { APP Import \& Export } \\
\text { Singapore }\end{array}$ & & & & * & & & & & & & & & & & & & & & & * & & & & \\
\hline APP Japan & & & & * & * & & & & & & & & & & & & & & & & & & & \\
\hline APP Malaysia & * & & & * & & & & & & & & & & & & & & & & & & & & \\
\hline APP Marketing Scandinavia & & & & & & & * & & & & & & & & & & & & & & & & & \\
\hline APP Printing Singapore & & & & & & & * & & ${ }^{*}$ & ${ }^{*}$ & ${ }^{*}$ & & & & & & & & & & & & & \\
\hline APP Paper Co Ltd & & & & & & & & & & & & & & & * & & & & & & & & & \\
\hline APP Singapore Pte Ltd & & & & & & & & & & & & & & & & & & & & * & & & & \\
\hline APP Scandinavia & * & & & & & & & & & & & & & & & & & & & & & & & \\
\hline APP Spain & & & & * & & & * & & * & ${ }^{*}$ & & & & & & & & & & & & & & \\
\hline APP International Trading & & & & & & & & & & & & & & & & * & & & & & & & & \\
\hline APP Taiwan & & & & & & & & & & & & & & & & & & & & * & & & & \\
\hline APP Trading Cayman Islands & & & & * & & & & & & * & & & & & & & & & & & & & & \\
\hline APP Trading Singapore & & & & * & & & & & & * & & & & ${ }^{*}$ & & & & & & & & & & \\
\hline APP Trading UK & & & & * & & & * & & & & & & & & & & & & & & & & & \\
\hline APP Trading USA & & & & * & & & & & * & & & & & & & & & & & & & & & \\
\hline APP Trading Virgin Islands & & & & * & & & & & & & & & & & & & & & & & & & & \\
\hline APP UK & & & & & & & & & ${ }^{*}$ & & & & & & & & & & & & & & & \\
\hline APP USA & * & & * & & & & * & & & & & & & & & & & & & & & & & \\
\hline Arara Abadi & & * & & & & & & & & & & & & * & & & & & & * & & & * & \\
\hline Asia Paperindo Perkasa & & & & & & & & & & & & & ${ }^{*}$ & & & & & & & & & & & \\
\hline Asia Trade Logistic & & & & & & & & & & & ${ }^{*}$ & & & & & & & & & & & & & \\
\hline Asuransi Sinar Mas & & & & & & & & * & & & & & & & & & & & & * & & & & \\
\hline Bina Sinar Transportation & & & & & * & & & & & & & & & & & & & & & & & & & \\
\hline Bina Sinar Utama & & * & & & & & & & & & & & & & & & & & & & & & & \\
\hline Cakrawala Mega Indah & * & * & & & * & & * & * & & & ${ }^{*}$ & & * & * & & & & & * & ${ }^{*}$ & & * & & \\
\hline Capania Trading, UEA & & & & * & & & & & & & & & & & & & & & & & & & & \\
\hline Collins Office, Virgin Islands & & & & & & & & & & * & & & & & & & & & & & & & & \\
\hline Dian Swastika Sentosa & & * & & & & & & & & & & & & ${ }^{*}$ & & & & & & & & & & \\
\hline Dinamika Mustika & & & & & & & & & & & & & & & & & & & & & & & & * \\
\hline Duta Teguh Paperindo Nusa & & & & & & & & * & & & & & & & & & & & & & & & & \\
\hline Ekamas Fortuna & * & * & & & & & * & * & & & $*$ & & & & & & & & & & & & & \\
\hline
\end{tabular}




\begin{tabular}{|c|c|c|c|c|c|c|c|c|c|c|c|c|c|c|c|c|c|c|c|c|c|c|c|c|}
\hline \multirow{2}{*}{ Company Name } & \multicolumn{6}{|c|}{ Indah Kiat } & \multicolumn{6}{|c|}{ Tjiwi Kimia } & \multicolumn{6}{|c|}{ Pindo Deli } & \multicolumn{6}{|c|}{ Lontar Papyrus } \\
\hline & \begin{tabular}{|l|}
$\mathrm{CR}$ \\
\end{tabular} & ST & $\mathrm{AP}$ & NR & $\mathrm{D}$ & IN & CR & ST & $\mathrm{AP}$ & NR & $\mathrm{D}$ & IN & CR & ST & $\mathrm{AP}$ & NR & $\mathrm{D}$ & IN & $\mathrm{CR}$ & ST & $\mathrm{AP}$ & NR & $\mathrm{D}$ & IN \\
\hline Gold East Paper China & * & & & * & & & & & & & & & & & & & & & & & & & * & \\
\hline Gold Hong Ye Papers & & & & & & & & & & & & & & & & & & & & & & & * & \\
\hline Linden Trading USA & & & * & & & & * & * & * & & * & & & & & & & & & & & & & \\
\hline IK Import \& Export & & * & & & & & & & & & & & & & & & & & & & & & & \\
\hline Intercipta Kimia Pratama & & * & & & & & & & & & & & & & & & & & & & & & & \\
\hline Jin Xin Paper China & * & & & & & & * & & & * & & & & & & & & & & & & & & \\
\hline Karawang Ekawarna & & & & & & & & & & & & & & & & & & & & & & & & * \\
\hline Kerawang Bukit Golf & & * & & & & & & & & & & & & & & & & & & & & & & \\
\hline Kinno Ltd & & & & & & & & & & * & & & & & & & & & & & & & & \\
\hline Konverta Mitra Abadi & * & & & & & & & & & & & & & & & & & & & & & & & \\
\hline Linden Trading USA & & & * & & & & * & * & * & & * & & & & & & & & & & & & & \\
\hline Mega Kertas Pratama & & & & & & & & * & & & & & * & & & & & & & & & & & \\
\hline Ningbo Asia China & * & & & & & & & & & & & & & & & & & & & & & & & \\
\hline Ningbo Zhoghua, RRC & & & & & * & & & & & & & & & & & & & & & & & & & \\
\hline Nippercraft Singapore & * & & & & & & & & & & & & & & & & & & & & & & & \\
\hline PAK 2000 & & & & & & & * & & * & * & * & & & & & & & & & & & & & \\
\hline Paper Box Singapore & & & & * & & & & & & & & & & & & & & & & & & & & \\
\hline Paramita Gunakarya & & & & & & & & & & * & & & & & & & & & & & & & & \\
\hline Paramitra Abadimas & & & & & & * & & & & & & & & & & & & & & & & & & \\
\hline Persadamas Langgeng & & & & & & & & & & & & & & & & & & & & & & & & * \\
\hline Purinusa Ekapersada & & & & & * & & & & & & & & & & & & & & & & & & & \\
\hline Royal Oriental & & * & & & & & & * & & & & & & & & & & & & & & & & \\
\hline Satria Perkasa Agung & & & & & * & & & & & & & & & & & & & & & & & & & \\
\hline Sinarindo Pirantimas & & & & & & & & & & & & & & & & & & & & & * & & * & * \\
\hline Sinar Dunia Makmur & * & * & & & $*$ & & * & * & & & * & & & * & & & & & & * & & & & \\
\hline Sinar Mas Speciality Mineral & & * & & & & * & & & & & & & & & & & & & & & & & & \\
\hline Sinar Mas Holding & & & & & & & & & & & & & & & & & * & & & & & & & \\
\hline Summit Sinar Mas Finance & & * & & & & & & * & & & & & & & & & & & & & & & & \\
\hline Univenus Company & * & & & & & & & & & & & & * & & & * & & & * & * & & * & * & \\
\hline Vestwin Trading Singapore & * & * & * & & & & * & * & * & & * & & * & & & & & & & & & & & \\
\hline Wirakarya Sakti & & & & & & & & & & & & & * & * & * & & * & & & * & * & & & \\
\hline Yalong Paper Produc, RRC & & & & & & & * & & & & & & & & & & & & & & & & & \\
\hline Zhenjiang Dadong, RRC & & & & & * & & & & & & & & & & & & & & & & & & & \\
\hline
\end{tabular}

Source: Annual Reports of PT Indah Kiat Pulp \& Paper (2003), PT Pabrik Kertas Tjiwi Kimia (2002)

PT Pindo Deli (2003), and PT Lontar Papyrus (2003).

Categories: CR (Current Trade Receivable), ST (Significant Transaction to related parties), AP (Advance Payment), NR (Non Current Receivable),

D (Due), and IN (Investment)

- * means that there is a 'related party transaction' between companies 
The following are some more detailed examples of these transactions:

- In January 1998, PT Cakrawala Mega Indah (CMI) and PT Sinar Dunia Makmur (SDM) agreed to distribute Indah Kiat's production in the domestic market (pulp, paper and packaging products). This is very important as it gives the ultimate owners the opportunity to manipulate the sales prices as desired, and generate profits for whichever company they choose. These transactions are recorded under 'trade receivables to related parties.' Tjiwi Kimia is in the same situation.

- Tjiwi Kimia bought paper, directly or through its subsidiary PT Mega Kertas Pratama, from CMI, SDM, PT Ekamas Fortuna, Indah Kiat and Pindo Deli.

- Pindo Deli and Lontar sell their products to Vestwin Trading Pte Ltd, Tjiwi Kimia, Indah Kiat, Mega Kertas Pratama, CMI and PT Univenus $\mathrm{Co}$. These transactions are noted as 'trade receivables to related parties.'

- In July 1996, Indah Kiat entered into an exclusive contract with PT Sinar Mas Speciality Minerals (SMSM) for the supply of calcium carbonate megafil and albagloss. Indah Kiat also agreed to supply carbon dioxide gas to SMSM at no charge, and other resources and services (land, utilities and services, landfill, electrical services and usage and product storage) at their actual cost. SMSM promises to pay a management fee to the company. This is recorded under 'Due from Related Parties.' Indah Kiat also invested in SMSM and in the other chemical company, PT Paramitra Abadimas Cemerlang.

- Lontar Papyrus invested in PT Dinamika Mustika, PT Persadamas Langgeng, PT Sinarindo Pirantimas and PT Kerawang Ekawana Nugraha.
- Indah Kiat purchased raw materials from Linden Trading Company Incorporated (USA), Vestwin Trading Pte. Ltd (Singapore), PT Ekamas Fortuna and Intercipta Kimia Pratama (Indonesia). This is noted as 'trade payable to related parties' on the balance sheet. The company also provided advances to Linden and Vestwin, noted as 'Advance and Prepaid Expenses.'

- Indah Kiat used PT Binar Sinar Utama for transportation, and had a membership certificate in PT Kerawang Bukit Golf.

- Indah Kiat and Tjiwi Kimia entered into a sale and leaseback transaction with PT Summit Sinar Mas Finance. 


\section{Annex 4: APP Indonesia financial figures}

Table 6: Evolution of net profits (losses) for APP’s principal Indonesian mills' consolidated accounts ('000 US \$)

\begin{tabular}{lccccccccccc}
\hline & 1993 & 1994 & 1995 & 1996 & 1997 & 1998 & 1999 & 2000 & 2001 & 2002 & 2003 \\
\hline Indah Kiat & $\begin{array}{c}24,408 \\
\text { (to 30 June) }\end{array}$ & 66,782 & 204,601 & 111,030 & 84,403 & 325,126 & 4,027 & $(400,683)$ & $(182.391)$ & $(266.308)$ & $(286.631)$ \\
\hline Tjiwi Kimia & 37,391 & 23,088 & 73,849 & 60,888 & 74,929 & 113,704 & 103,989 & $(359,661)$ & $(50,682)$ & $(47,432)$ & $(30.270)$ \\
\hline Pindo Deli* & - & - & 32,885 & 22,641 & - & 76,713 & $(9,224)$ & $(375,813)$ & $(171,120)$ & $(119,463)$ & $(158.823)$ \\
\hline Lontar Papyrus & - & - & 77,090 & 19,550 & 91,670 & 55,350 & - & - & - & $(22,589)$ & $(38.539)$ \\
\hline IK + TK + PD + LP** & 61,799 & 89,870 & 388,425 & 194,559 & 251,002 & 515,543 & 98,792 & $(1,136,157)$ & $(404,193)$ & $(433,203)$ & $(448.481)$ \\
\hline
\end{tabular}

Source: Adapted from data published in Bisnis Indonesia.

Data are in '000 US dollars as at 31 December of the year concerned. For the period 1993 to 1997, amounts in Rupiah were converted into US dollars according to the exchange rate on 31 December.

*Pindo Deli's consolidated report includes Lontar Papyrus from 1996 onwards.

${ }^{* *}$ Not included: Pindo Deli for 1993, 1994, 1997. Starting 1996 Lontar Papyrus is accounted for in Pindo Deli, but for 1997 Lontar Papyrus is shown separately.

Table 7: Evolution of debt burden (principal plus interest payable during the year) for APP's principal Indonesian mills ('000 US \$)

\begin{tabular}{|c|c|c|c|c|c|c|c|c|c|c|c|}
\hline & 1993 & 1994 & 1995 & 1996 & 1997 & 1998 & 1999 & 2000 & 2001 & 2002 & 2003 \\
\hline Indah Kiat & $\begin{array}{c}6,901 \\
\text { (to } 30 \text { June) }\end{array}$ & 38,616 & 103,156 & 74,114 & 99,630 & 183,738 & 181,519 & 249,686 & 294,272 & 259,878 & 260,735 \\
\hline Tjiwi Kimia & 28,826 & 44,241 & 58,137 & 50,616 & 50,645 & 86,183 & 92,836 & 122,960 & 114,137 & 107,795 & 109,736 \\
\hline Pindo Deli* & - & - & 16,093 & 33,948 & - & 115,640 & 105,152 & 183,493 & 161,879 & 158,808 & 153,812 \\
\hline Lontar Papyrus & - & - & - & 38,642 & 35,290 & 43,042 & - & - & - & 47,962 & 49,982 \\
\hline $\mathrm{IK}+\mathrm{TK}+\mathrm{PD}+\mathrm{LP}^{* *}$ & 35,727 & 82,857 & 177,386 & 158,678 & 185,565 & 385,561 & 379,507 & 556,139 & 570,288 & 526,481 & 524,283 \\
\hline
\end{tabular}

Source: Adapted from data published in Bisnis Indonesia.

Data are in '000 US dollars as at 31 December of the year concerned. For the period 1993 to 1997, amounts

in Rupiah were converted into US dollars according to the exchange rate on 31 December.

*Pindo Deli consolidated report includes Lontar Papyrus from 1996 onwards.

** Not included: Pindo Deli for 1993, 1994, 1997. Starting in 1996, Lontar Papyrus is accounted for in Pindo Deli, but for 1997 Lontar Papyrus is shown separately. 
Table 8: Evolution of sales for APP's principal Indonesian mills ('000 US \$)

\begin{tabular}{lccccccccccc}
\hline & 1993 & 1994 & 1995 & 1996 & 1997 & 1998 & 1999 & 2000 & 2001 & 2002 & 2003 \\
\hline Indah Kiat & $\begin{array}{c}147,514 \\
\text { (to 30 June) }\end{array}$ & 474,436 & 906,536 & 760,585 & 634,073 & $1,158,112$ & $1,306,288$ & $1,544,275$ & $1,100,228$ & $1,197,712$ & $1,345,832$ \\
\hline Tjiwi Kimia & 292,044 & 382,052 & 543,159 & 583,764 & 434,534 & 631,391 & 868,254 & 827,984 & 710,418 & 778,498 & 870,143 \\
\hline Pindo Deli* & & & 225,645 & 284,401 & & 534,305 & 727,315 & 760,522 & 619,199 & 743,366 & 785,259 \\
\hline Lontar Papyrus & & & & 196,121 & 221,937 & 217,325 & & & & 250,532 & 254,563 \\
\hline IK + TK + PD + LP** & 439,558 & 856,488 & $1,675,340$ & $1,628,750$ & $1,068,607$ & $2,323,808$ & $2,901,857$ & $3,132,781$ & $2,429,845$ & $2,719,576$ & $3,001,234$
\end{tabular}

Source: Adapted from data published in Bisnis Indonesia.

Data are in '000 US dollars as at 31 December of the year concerned. For the period 1993 to 1997, amounts

in Rupiah were converted into US dollars according to the exchange rate on 31 December.

*Pindo Deli consolidated report includes Lontar Papyrus from 1996 onwards.

**Not included: Pindo Deli for 1993, 1994, 1997. Starting 1996, Lontar Papyrus is accounted for in Pindo Deli, but for 1997 Lontar Papyrus is shown separately.

Table 9: evolution of operating costs (not included marketing costs and overhead costs) for APP's principal Indonesian mills ('000 US \$)

\begin{tabular}{lcccccccccccc}
\hline & 1993 & 1994 & 1995 & 1996 & 1997 & 1998 & 1999 & 2000 & 2001 & 2002 & 2003 \\
\hline Indah Kiat & $\begin{array}{c}127,338 \\
\text { (to 30 June) }\end{array}$ & 280,760 & 499,230 & 501,563 & 326,936 & 554,912 & 768,719 & $1,011,721$ & 904,398 & $1,028,989$ & $1,193,132$ \\
\hline Tjiwi Kimia & 207,407 & 244,640 & 360,748 & 424,985 & 291,208 & 394,364 & 586,476 & 770,959 & 552,510 & 613,818 & 676,276 \\
\hline Pindo Deli* & & & 161,797 & 208,098 & & 275,151 & 479,603 & 641,136 & 531,700 & 612,254 & 673,004 \\
\hline Lontar Papyrus & & & & 122,906 & 120,845 & 79,888 & & & & & 194,306 & 211,876 \\
\hline IK + TK + PD + LP** & 334,745 & 305,224 & $1,021,775$ & $1,134,646$ & 618,144 & $1,224,427$ & $1,834,798$ & $2,423,816$ & $1,988,608$ & $2,255,061$ & $2,542,412$ \\
\hline
\end{tabular}

Source: Adapted from data published in Bisnis Indonesia.

Data are in '000 US dollars as at 31 December of the year concerned. For the period 1993 to 1997, amounts

in Rupiah were converted into US dollars according to the exchange rate on 31 December.

*Pindo Deli consolidated report includes Lontar Papyrus from 1996 onwards.

** Not included: Pindo Deli for 1993, 1994, 1997. Starting 1996, Lontar Papyrus is accounted for in Pindo Deli, but for 1997 Lontar Papyrus is shown separately. 
Graph 1: Evolution of debt to equity ratio for APP's principal Indonesian Pulp \& Paper mills

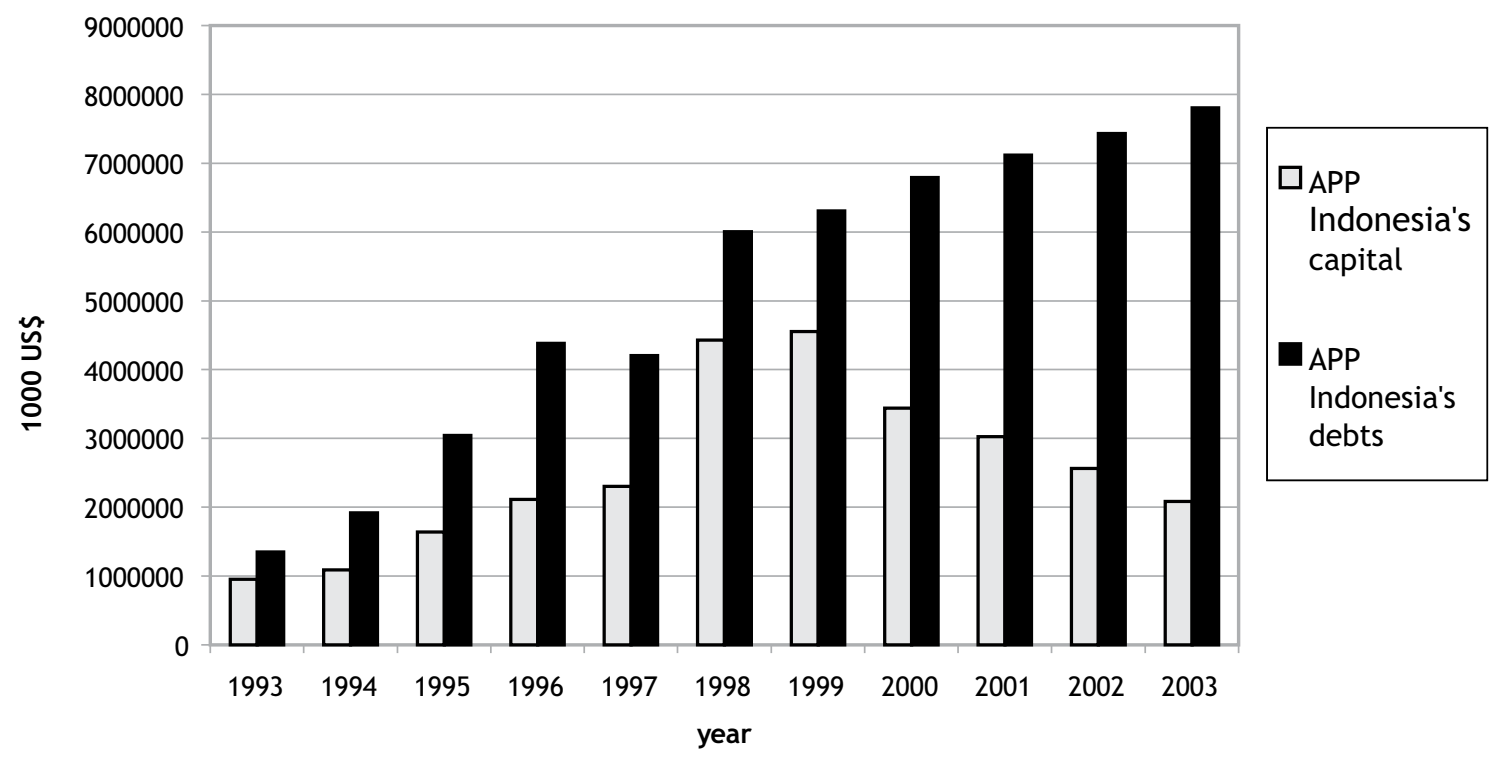

Source: Adapted from consolidated financial reports of Indah Kiat, Tjiwi Kimia and Pindo Deli (the later not included for 1993, 1994, 1997) 
Asia Pulp \& Paper (APP) has expanded impressively during the 1990 s to become the largest pulp and paper producer in Asia outside Japan, and one of the top ten producers in the world. In March 2001, the group suddenly announced a debt standstill on $\$ 13$ billion, after many years of high profits due to very low production costs. The group is controlled by the Widjaja family members, its ultimate owners, who have been able to finance most of the expansion in Indonesia through domestic and international debts (bank loans or bonds). This family also controls Sinar Mas, which is one of the top Indonesian conglomerates. The pyramid structure of APP allows the ultimate owners to dilute their direct investment along a chain of intermediaries, while keeping control of the decisions and accounts. Research in finance has proved that this well-known strategy of reducing the ownership rights relative to the voting rights, usually causes poor corporate governance and reduced business performance. This phenomenon was particularly true in the case of the Asian type corporate model with its highly concentrated ownership in the hands of families. We found numerous transactions between APP and Sinar Mas affiliated companies, and these appear to suggest the use of transfer pricing. In particular, we are concerned by the possible instrumental use of the companies in charge of wood supply (the main operational cost for the pulp industry), and which are presumably owned by the ultimate owners without any control by minority shareholders and creditors of APP. The rents resulting from the clearing of natural forests to supply mills, which we estimate, were unusually high. The main use of debts to finance the enormous investments of APP is also remarkable for two reasons: huge profits were made in the short term owing to a low cost access to natural forests in Indonesia; and the creditors' rights could never be satisfied due to poor law enforcement and the absence of a cross-border insolvency regime in the Asia-Pacific region. This suggests that APP is a case of debt entrenchment, the theory of which says that conglomerates use debts to prioritize the ultimate owners' interests to the detriment of minority shareholders and external creditors. Finally, some facts suggest that politics were also important in the ability of the group to survive, as the Indonesian government held back claims on domestic debts and influenced the debt restructuring process.

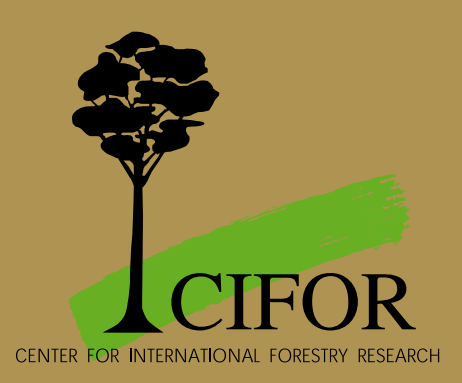

